\title{
The Role of Forests in Climate Change Regarding Carbon, Nitrogen, and Water: A Case Study of Pinus densiflora
}

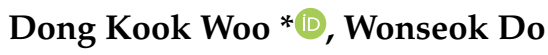 \\ Department of Civil Engineering, Keimyung University, 1095 Dalgubeoldaero, Dalseo-gu, Daegu 42601, Korea; \\ 5397378@stu.kmu.ac.kr \\ * Correspondence: dkwoo@kmu.ac.kr
}

check for updates

Citation: Woo, D.K.; Do, W. The Role of Forests in Climate Change Regarding Carbon, Nitrogen, and Water: A Case Study of Pinus densiflora. Water 2021, 13, 3050. https://doi.org/10.3390/w13213050

Academic Editor: YongJiang Zhang

Received: 22 August 2021

Accepted: 29 October 2021

Published: 1 November 2021

Publisher's Note: MDPI stays neutral with regard to jurisdictional claims in published maps and institutional affiliations.

Copyright: (c) 2021 by the authors. Licensee MDPI, Basel, Switzerland. This article is an open access article distributed under the terms and conditions of the Creative Commons Attribution (CC BY) license (https:/ / creativecommons.org/licenses/by/ $4.0 /)$.

\begin{abstract}
We examined the influence of climate change on the dynamics of Pinus densiflora, the most dominant tree species in South Korea, to explore its potential for climate change mitigation. We considered changes in precipitation, temperature, and $\mathrm{CO}_{2}$ under four representative concentration pathway (RCP) scenarios separately and in combination to evaluate the responses of Pinus densiflora to climate change. A well-tested ecohydrological and biogeochemical model, ecosys, was used to study the Gwangneung Experimental Forest in South Korea. Results showed that the positive effects of $\mathrm{CO}_{2}$ fertilizer on gross primary productivity (GPP) and net primary productivity (NPP) outweighed the negative effects caused by changes in precipitation and temperature. In particular, NPP improvements of $3.79 \%, 13.44 \%, 18.26 \%$, and $28.91 \%$ were modeled under RCP values of 2.6, 4.5, 6.5 , and 8.5 , respectively, compared to the baseline. We found that nitrogen leaching and $\mathrm{N}_{2} \mathrm{O}$ flux reduced as climate change become severe due to increases in nutrient uptake, leading to reduced soil nitrogen losses. Although evapotranspiration increased as the intensity of climate change increased, reductions in the stomatal opening improved the water use efficiency of Pinus densiflora. These results indicated that Pinus densiflora could serve as an environmentally friendly option to minimize climate change consequences.
\end{abstract}

Keywords: Pinus densiflora; GPP; NPP; water use efficiency; $\mathrm{CO}_{2}$ fertilization

\section{Introduction}

Global climate is changing at faster rates than any change documented in historical records [1]. Ecohydrological processes such as gross primary productivity (GPP), net primary productivity (NPP), and evapotranspiration have become non-stationary and highly variable due to global warming $[2,3]$. Changes in precipitation intensity and seasonal variability have been observed across time and space [4]. In particular, these changes are important to maintain the ecological balance in the Korean peninsula, because more than $50 \%$ of the annual precipitation occurs between April and September (the summer monsoon season) [5]. That is, a perturbation in precipitation patterns may have great potential to degrade ecosystem health. With the acceleration in global warming, South Korea experienced an unprecedented rise in summer temperature in 2018 [6]. The maximum temperature in Hongcheon in South Korea reached $40.3^{\circ} \mathrm{C}$ during the summer, which was the highest temperature ever recorded since 1907 [7].

In recent years, a number of studies have addressed various aspects of climate change on forest ecosystem dynamics [8-10]. One of the most imperative characteristics regarding the influences of climate change on forest ecosystems is their regional response to climate change [10,11]. In South Korea, Pinus densiflora, a focus of this study, is the most widely grown tree ( $\sim 27 \%$ of forest areas). This tree has been restored under a forest development plan since the 1970s [12,13]. Previous studies found that under representative concentration pathway (RCP) 8.5 scenarios, the Pinus densiflora growth rate would decrease by the $2050 \mathrm{~s}$ in South Korea [14-17]. However, mechanistic explanations were limited in these studies, 
since they were primarily based on statistical trend analysis using age, density, stand growth, and topography wetness index. A causal assessment of how climate change affects forest productivity and ecosystem carbon balance needs exploring to understand the complex relationship between climate stresses and their effects on the growth of Pinus densiflora.

Several studies have found that planting trees could slow global warming by absorbing atmospheric $\mathrm{CO}_{2}$ through photosynthesis [18-20]. Forest ecosystems account for $\sim 45 \%$ of global terrestrial carbon storage [21] and have the ability to offset $\sim 33 \%$ of carbon emissions from anthropogenic activities, such as fossil fuels and land-use changes [22]. However, the beneficial carbon sequestration capacity of forest ecosystems was primarily estimated focusing on $\mathrm{CO}_{2}$ fertilization benefits. Elevated temperature and changes in precipitation patterns also influenced forest carbon storage. Warmer temperatures increase soil respiration through its positive effects on microbial growth and activity, which could reverse forests from a net carbon sink into a source [23]. Changes in precipitation alter forest growth and primary productivity dependent on water availability [24]. That is, the ability of forest ecosystems to help absorb atmospheric carbon is likely to be affected by a combination of climate change, tree phenology, and soil, water and nutrient dynamics.

The effects of these complex dynamics on the growth of Pinus densiflora must be considered together to assess the potential of Pinus densiflora to mitigate climate change in the long term. Addressing these intertwined dynamics discussed above is the focus of this study. In particular, we explored the following questions to evaluate the sustainability of Pinus densiflora under climate change: (1) How do changes in precipitation, temperature, and $\mathrm{CO}_{2}$ separately and in combination affect the GPP and NPP of Pinus densiflora?; (2) Are soil $\mathrm{N}_{2} \mathrm{O}$ flux and nitrogen leaching sensitive to climate change since they are emerging environmental issues?; (3) Does water availability become a limiting factor to sustain the growth of Pinus densiflora under climate change? To answer these questions, we used a coupled ecohydrological and biogeochemical model, ecosys, to investigate the potential of Pinus densiflora to minimize climate change consequences.

\section{Materials and Methods}

\subsection{Study Site}

We studied the growth and physiology of Pinus densiflora under climate change for the case of the Gwangneung Experimental Forest near Seoul, South Korea $\left(37^{\circ} 47^{\prime} 01^{\prime \prime} \mathrm{N}\right.$, $127^{\circ} 10^{\prime} 37^{\prime \prime} \mathrm{E}, \sim 420 \mathrm{~m}$ above sea level). Pinus densiflora was chosen since it was one of the most dominant tree species in this study site [25]. This experimental forest has been protected from human activities since 1913 and thus is home to plants and animals designated as endangered [14]. Even during the period of Japanese colonialism (1910-1945) and the Korean War (1950-1953), these forest regions were not greatly affected by physical disturbances, such as clear cuttings and winter heating [25,26]. In 1998, a long-term ecological research (LTER) site was established in this region to monitor the sustainability of forest ecosystems.

The long-term annual mean precipitation and temperature of the study site are $1468 \mathrm{~mm}$ and $12.70{ }^{\circ} \mathrm{C}$, respectively, based on weather data from the Korea Meteorological Administration (https: / / data.kma.go.kr). The most precipitation falls in July, with an average of $436 \mathrm{~mm}$, while the lowest precipitation occurs in January, with an average of $19 \mathrm{~mm}$. In terms of temperature, the hottest month is August (average temperature of $25.78{ }^{\circ} \mathrm{C}$ ) while the coolest month is January (average temperature of $-2.11^{\circ} \mathrm{C}$ ). That is, the study site experiences high seasonal variations in monthly precipitation and temperature. For soil conditions, we used silt loam with a bulk density of $1.05 \mathrm{~g} \mathrm{~cm}^{-3}$ obtained from [25] and the vertical profile of soil organic carbon and $\mathrm{pH}$ obtained from Soil Grid [27]. Based on the soil type, we estimated the hydraulic conductivity and field capacity to be $28 \mathrm{~mm} \mathrm{hr}^{-1}$ and 0.28 , respectively [28]. All these soil characteristics were used for soil parameters.

Hourly weather forcings, such as precipitation, air temperature, specific humidity, wind speed, and solar radiation, were obtained at an adjacent site ( $\sim 30 \mathrm{~km}$ away) to the 
Korea Meteorological Administration for the 30 years from 1986 to 2015 (https:/ / data.kma. go.kr). We performed simulations for 2006 to 2015 to evaluate the model performance. During the period, the observations of GPP, net ecosystem exchange (NEE), and soil temperature were available at the study site [29]. These observed variables were used for model validation to establish confidence in using the model to explore Pinus densiflora dynamics under climate change.

\subsection{Model Description}

In this study, we used ecosys to estimate Pinus densiflora growth and response to climate change. Multiple canopies and soil layers were used to estimate interactions between water, carbon, nitrogen, and phosphorus dynamics in the soil and plants. This model has been used in more than 100 studies across space and time to explore ecohydrological and biogeochemical processes in terrestrial ecosystems, including in agriculture [30,31], tundra [32,33], and forests [34-36]. This model was considered to be one of the most accurate models among 26 land surface models exploring GPP at 39 flux tower sites in North America [37]. In this paper, we briefly describe key processes associated with GPP and NPP dynamics modeled in ecosys, but do not list their detailed implementations. A detailed description of ecosys, including parameters, is available in supplementary materials in a previous study [38].

\subsubsection{Gross Primary Productivity}

In ecosys, the $\mathrm{C} 3$ and $\mathrm{C} 4$ carbon fixation pathways are considered to capture physiological and morphological differences in response to environmental conditions, such as atmospheric $\mathrm{CO}_{2}$, precipitation, and temperature. GPP is modeled as a sum of the $\mathrm{CO}_{2}$ fixation rate of each leaf surface for each branch, node, azimuth, and sun exposure [38] and is estimated through an iterative procedure until leaf $\mathrm{CO}_{2}$ fixation rate $\left(V_{c},\left[\mu \mathrm{mol} \mathrm{m}{ }^{-2} \mathrm{~s}^{-1}\right]\right)$ is equal to leaf diffusion rate $\left(V_{g}\left[\mu \mathrm{mol} \mathrm{m}{ }^{-2} \mathrm{~s}^{-1}\right]\right)$. This equilibrium is achieved by adjusting $V_{c}$ using a convergence solution for $\mathrm{CO}_{2}$ in canopy leaf $\left(C_{i}\left[\mu \mathrm{mol} \mathrm{mol}^{-1}\right]\right)$ and $\mathrm{CO}_{2}$ in canopy chloroplasts $\left(C_{c}\left[\mu \mathrm{mol} \mathrm{mol}^{-1}\right]\right)$ :

$$
G P P=\sum\left(V_{c}=V_{g}\right) A
$$

where

$$
\begin{gathered}
V_{c}=\min \left\{V_{b}, V_{j}\right\} \\
V_{g}=\frac{\left(C_{b}-C_{i}\right)}{r_{l}}
\end{gathered}
$$

where $A$ is the leaf area $\left[\mathrm{m}^{2} \mathrm{~m}^{-2}\right] ; V_{b}$ is the $\mathrm{CO}_{2}$-limited leaf carboxylation rate $[\mu \mathrm{mol}$ $\left.\mathrm{m}^{-2} \mathrm{~s}^{-1}\right] ; V_{j}$ is the irradiance-limited leaf carboxylation rate $\left[\mu \mathrm{mol} \mathrm{m} \mathrm{m}^{-2} \mathrm{~s}^{-1}\right] ; C_{b}$ is $\mathrm{CO}_{2}$ in canopy air $\left[\mu \mathrm{mol} \mathrm{mol}^{-1}\right] ; r_{l}$ is leaf stomatal resistance $\left[\mathrm{s} \mathrm{m}^{-1}\right] . V_{b}$ and $V_{j}$ are modeled as:

$$
V_{b}=V_{b, \max } \frac{C_{c}-\Gamma}{C_{c}+K_{c}} f_{\psi}
$$

and

$$
V_{j}=J Y f_{\psi}
$$

where $V_{b, \max }$ is the leaf carboxylation rate at non-limiting $\mathrm{CO}_{2}$, water, temperature, nitrogen and phorspous $\left[\mu \mathrm{mol} \mathrm{m}{ }^{-2} \mathrm{~s}^{-1}\right] ; C_{c}$ is the $\mathrm{CO}_{2}$ in canopy chloroplasts $[\mu \mathrm{M}] ; \Gamma$ is the $\mathrm{CO}_{2}$ compensation point in a $\mathrm{C}_{3}$ mesophyll $[\mu \mathrm{M}] ; K_{c}$ is the Michaelis-Menten constant for carboxylation at ambient $\mathrm{O}_{2} ; f_{\psi}$ is the non-stomatal water effect on carboxylation [-]; $J$ is the electron transport rate in a C3 mesophyll $\left[\mu \mathrm{mol} \mathrm{m}^{-2} \mathrm{~s}^{-1}\right]$; and $Y$ is the carboxylation yield from electron transport in a $\mathrm{C} 3$ mesophyll $\left[\mu \mathrm{mol} \mathrm{CO} 2 \mu \mathrm{mol} \mathrm{e}^{-1}\right]$. 


\subsubsection{Net Primary Productivity}

Net primary productivity (NPP) is modeled as GPP minus total autotrophic respiration $\left(R_{a}\left[\mathrm{~g} \mathrm{C} \mathrm{m}^{-2} \mathrm{~h}^{-1}\right]\right)$ from a nonstructural carbon product of $\mathrm{CO}_{2}$ fixation $\left(R_{c}\left[\mathrm{~g} \mathrm{C} \mathrm{g} \mathrm{C}^{-1}\right]\right)$,

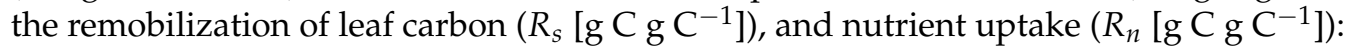

$$
N P P=G P P-R_{a}
$$

where

$$
R_{a}=R_{c}+R_{s}+R_{n}
$$

$R_{c}$ is estimated by the multiplication of the specific autotrophic respiration of a nonstructural carbon product of $\mathrm{CO}_{2}$ fixation, a nonstructural carbon product of $\mathrm{CO}_{2}$ fixation, and the temperature effect. $R_{S}$ is modeled as the difference between the autotrophic respiration of a nonstructural carbon product of $\mathrm{CO}_{2}$ fixation and maintenance respiration. $R_{n}$ is modeled as:

$$
R_{n}=E_{N, P}\left(U_{N H 4}+U_{N O 3}+U_{P O 4}\right)
$$

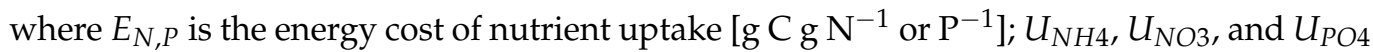
are root or mycorrhizae ammonium uptake $\left[\mathrm{g} \mathrm{N} \mathrm{m}^{-2} h^{-1}\right]$, nitrate uptake $\left[\mathrm{g} \mathrm{N} \mathrm{m}^{-2}\right.$, and dihydrogen phosphate uptake $\left[\mathrm{g} \mathrm{P} \mathrm{m}^{-2} h^{-1}\right]$, respectively. That is, NPP is strongly controlled by climate, $\mathrm{CO}_{2}$, and nutrient availability in plants directly through photosynthesis and respiration and indirectly through nutrient remobilization from storage roots to leaves and vice versa.

\subsection{Climate Scenarios}

In this study, we used four representative concentration pathway (RCP) scenarios (RCP2.6, RCP4.5, RCP6.5, and RCP8.5) to determine whether Pinus densiflora would help curb climate change through the process of capturing atmospheric $\mathrm{CO}_{2}$. To investigate its potential effects on climate change mitigation, seasonal changes in $\mathrm{CO}_{2}$, precipitation, and maximum and minimum temperature were considered (Table 1). We explored the growth and climate sensitivity of Pinus densiflora under baseline (1986 to 2015) and climate change conditions (the 2050s: 2036 to 2065). These 30-year periods were chosen to minimize seasonal and interannual weather variability. The seasonal climate change scenarios were estimated from the average values of 48 general circulation model (GCM) ensembles using KNMI Climate Explorer (https:/ / climexp.knmi.nl). More details can be found in KNMI Climate Explorer. Four different atmospheric $\mathrm{CO}_{2}$ concentrations were used for RCP2.6, RCP4.5, RCP6.5, and RCP8.5, which were 440, 480, 485, and 550 ppm, respectively. The baseline was evaluated at the present concentration of $\mathrm{CO}_{2}(400 \mathrm{ppm})$.

Table 1. Climate change scenarios. Comparisons of seasonal changes in $\mathrm{CO}_{2}$, precipitation (PPT), and minimum (Min) and maximum (Max) temperature (Temp) were considered under four different RCP

\begin{tabular}{|c|c|c|c|c|c|}
\hline Scenario & Season & $\mathrm{CO}_{2}(\mathrm{ppm})$ & PPT (\%) & $\begin{array}{c}\text { Min Temp } \\
\left({ }^{\circ} \mathrm{C}\right)\end{array}$ & $\begin{array}{c}\text { Max Temp } \\
\left({ }^{\circ} \mathrm{C}\right)\end{array}$ \\
\hline$R C P 2.6$ & $\begin{array}{l}\text { Dec-Feb } \\
\text { Mar-May } \\
\text { Jun-Aug } \\
\text { Sep-Nov }\end{array}$ & 440 & $\begin{array}{l}1.04 \\
1.06 \\
1.04 \\
1.03\end{array}$ & $\begin{array}{l}1.20 \\
1.08 \\
1.21 \\
1.23\end{array}$ & $\begin{array}{l}1.22 \\
1.14 \\
1.28 \\
1.24\end{array}$ \\
\hline$R C P 4.5$ & $\begin{array}{l}\text { Dec-Feb } \\
\text { Mar-May } \\
\text { Jun-Aug } \\
\text { Sep-Nov }\end{array}$ & 480 & $\begin{array}{l}1.04 \\
1.06 \\
1.06 \\
1.04\end{array}$ & $\begin{array}{l}1.59 \\
1.45 \\
1.57 \\
1.60\end{array}$ & $\begin{array}{l}1.60 \\
1.45 \\
1.59 \\
1.65\end{array}$ \\
\hline
\end{tabular}
pathways (RCP2.6, RCP4.5, RCP6.5, and RCP8.5) between the baseline in the 2010s (from 1986 to 2015) and 2050s (2036 to 2065). These data were obtained from KNMI Climate Explorer (https:/ / climexp.knmi.nl). 
Table 1. Cont.

\begin{tabular}{cccccc}
\hline \multirow{2}{*}{ Scenario } & Season & $\mathbf{C O}_{\mathbf{2}}(\mathbf{p p m})$ & PPT (\%) & $\begin{array}{c}\text { Min Temp } \\
\left({ }^{\circ} \mathbf{C}\right)\end{array}$ & $\begin{array}{c}\text { Max Temp } \\
\left({ }^{\circ} \mathbf{C}\right)\end{array}$ \\
\hline \multirow{3}{*}{ RCP6.0 } & & 1.01 & & \\
& Dec-Feb & & 1.05 & 1.38 & 1.40 \\
& Mar-May & 485 & 1.03 & 1.19 & 1.20 \\
& Jun-Aug & & 1.05 & 1.18 & 1.23 \\
& Sep-Nov & & & 1.35 & 1.41 \\
& & & & \\
\multirow{2}{*}{ RCP8.5 } & & 1.07 & 2.17 & 2.23 \\
& Dec-Feb & & 1.09 & 1.97 & 1.98 \\
& Mar-May & \multirow{2}{*}{550} & 1.07 & 2.10 & 2.13 \\
& Jun-Aug & & 1.06 & 2.22 & 2.33 \\
\hline
\end{tabular}

To achieve statistical confidence in the results of Pinus densiflora growth projections under climate change, we simulated ecosys for 50 years using a weather generator [39], which was used to reproduce a set of hourly meteorological variables including precipitation, temperature, solar radiation, relative humidity, wind speed, atmospheric pressure, and cloud cover (Figure 1). The inputs of the weather generator, except for the listed weather variables, included latitude, longitude, hours of difference from Greenwich Mean Time, and elevation. We used observed weather data from 1986 to 2015 to estimate the parameters of the weather generator. For the baseline scenario, the reproduced weather data were implemented to determine the effect of interannual weather variations in Pinus densiflora growth projections. For the climate change scenario, changes in $\mathrm{CO}_{2}$, precipitation, and minimum and maximum temperature were applied to the baseline scenario.
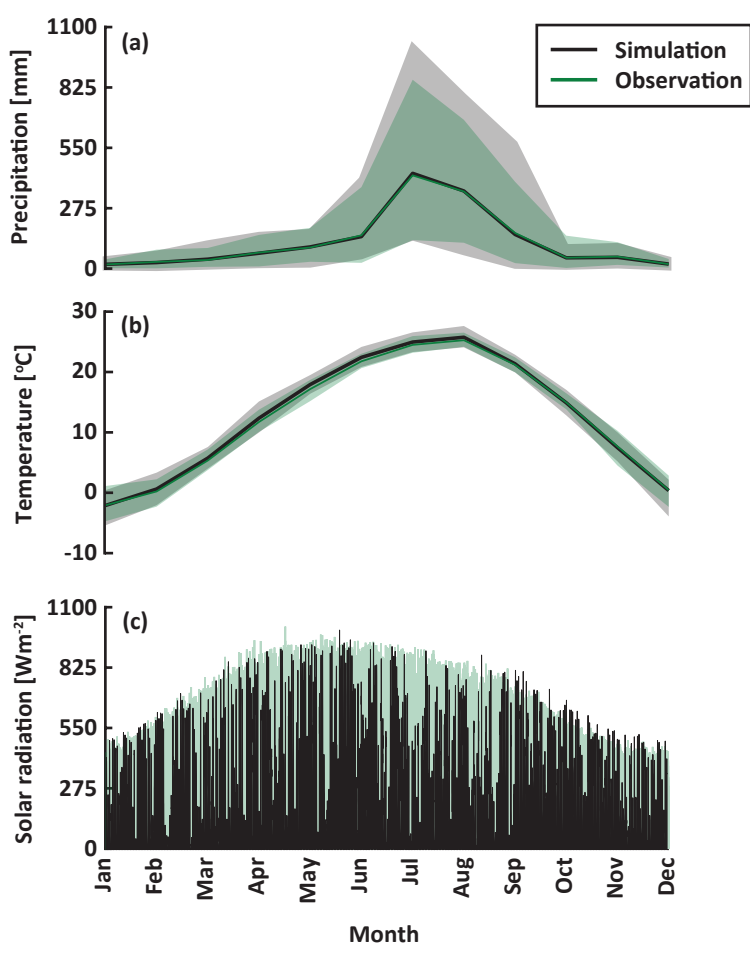

Figure 1. Observed (green) and reproduced (black) weather forcing data. A total of 50 years of hourly weather data were reproduced using a stochastic weather generator based on observations from 1986 to 2015. The 50th percentile (lines) and 5th to 95th percentile intervals (shaded areas) of the multi-year ensemble are shown for: (a) monthly precipitation, (b) monthly temperature, and (c) hourly solar radiation. 


\subsection{Simulation Design}

To reduce the influences of initial soil and canopy conditions on the modeled results, we ran ecosys for a 20-year spinup period (1986 to 2005) with the same set of equations and parameters as used in the following numerical experiments. The outputs of this preceding period were used as the initial conditions for model validations and applications. The present-day ecohydrological and biogeochemical dynamics for Pinus densiflora were estimated forward in time through the historical period until 2015 using observed weather. We then perform numerical experiments to investigate the impacts of climate change on the growth and carbon fixation of Pinus densiflora. For the parameters of Pinus densiflora, we used approaches described in previous studies [40-42]. Other parameters used in this study are provided in supplementary materials in a previous study [38].

\section{Results}

\subsection{Model Validation}

We compared the modeled results with observations at the study site over seven years (2006 to 2012); these observations included GPP, NEE, and soil temperature at a depth of $15 \mathrm{~cm}$ (Figure 2). The predicted variables through numerical estimations satisfactorily captured their seasonal variations. The corresponding root mean square errors (RMSE) were $1.6 \mathrm{~g} \mathrm{C} \mathrm{m}^{-2} \mathrm{~d}^{-1}, 1.4 \mathrm{~g} \mathrm{C} \mathrm{m}^{-2} \mathrm{~d}^{-1}$, and $3.0^{\circ} \mathrm{C}$ for GPP, NEE and soil temperature, respectively. In particular, our results showed excellent agreement between modeled and observed seasonal trends in soil temperature (Figure 2e,f). However, there were some discrepancies between modeled and observed GPP and NPP, especially during high flux events. These differences were in part caused by weather forcing data that were not obtained from the study, as explained above. However, the seasonal variations and magnitudes of GPP, NEE, and soil temperature were comparable with the observations, providing confidence in modeled results for exploring the growth of Pinus densiflora under climate change.
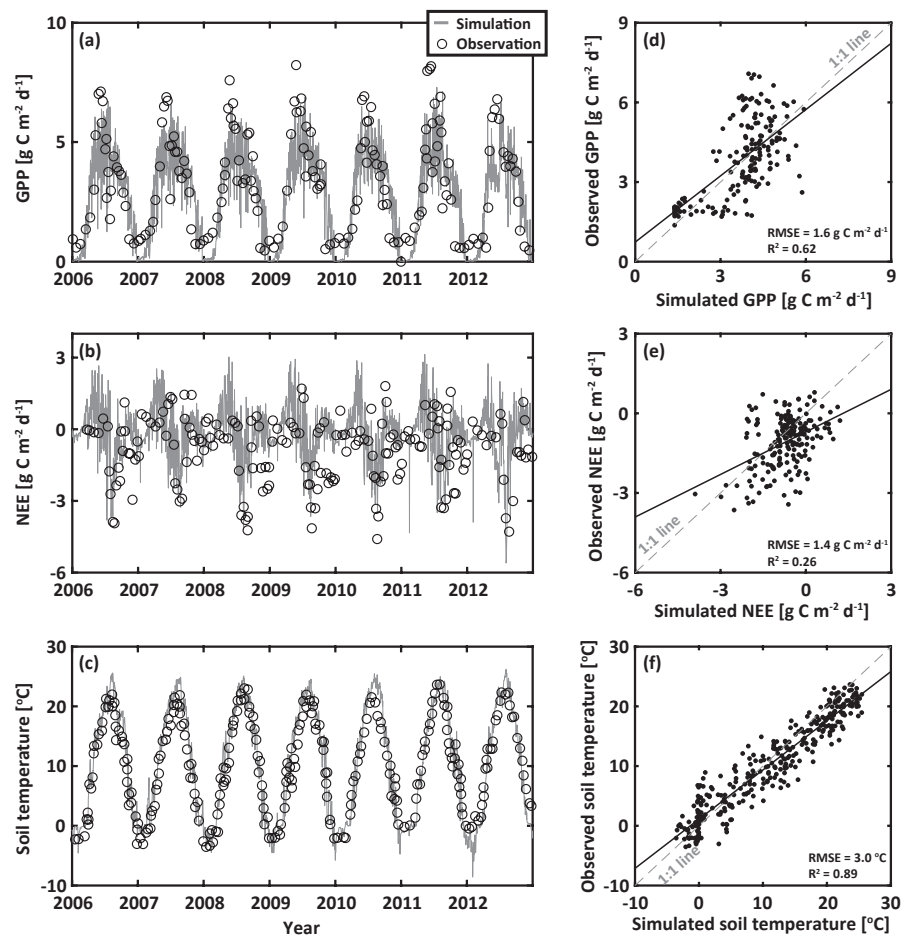

Figure 2. Model validation: (a) predicted (gray lines) and observed (circles) GPP (RMSE $=1.6 \mathrm{~g} \mathrm{C} \mathrm{m}^{-2}$ $\left.\mathrm{d}^{-1}\right),(\mathbf{b})$ NEE (RMSE $\left.=1.4 \mathrm{~g} \mathrm{C} \mathrm{m}^{-2} \mathrm{~d}^{-1}\right)$, and (c) soil tmperature to a depth of $0.15 \mathrm{~m}\left(\mathrm{RMSE}=3^{\circ} \mathrm{C}\right)$ during the model validation period from 2006 to 2012. The corresponding results were presented in (d-f), respectively. The gray dashed line in $(\mathbf{d}-\mathbf{f})$ represents the 1:1 relationship. 


\subsection{GPP and NPP}

We estimated separately and in combination the impacts of precipitation, temperature, and $\mathrm{CO}_{2}$ concentration under four different RCP scenarios (RCP2.6, RCP4.5, RCP6.0, and RCP8.5) on the GPP and NPP of Pinus densiflora (Figure 3). An increase in precipitation was projected in all seasons, with larger increases in higher greenhouse gas emission scenarios (Table 1). For the scenario of precipitation change alone, our results showed that changes in precipitation did not considerably alter GPP and NPP compared to baseline (Figure 3, first column). The percentage changes of GPP and NPP under climate change scenarios compared to baseline were less than $0.2 \%$. At a first glance, water availability would not be a limiting factor to the rate of Pinus densiflora photosynthesis and soil respiration. However, the small changes in GPP and NPP were indeed caused by the balance between two opposite effects: (i) reduced oxygen in the root zone, which lowered nutrient uptake and thus photosynthesis, and (ii) improved photosynthesis and respiration under well-watered conditions.

For the scenario of temperature change alone, slight changes in GPP of $-0.69 \%$, $-0.23 \%,-0.48 \%$, and $0.89 \%$ under RCP $2.6,4.5,6.0$, and 8.5 , respectively, were modeled compared to baseline (Figure 3, second column). The potential improvement of photosynthesis due to increased kinetic energy under elevated temperature was offset by increased water stress. Warming led to an increase in the energy used to support evaporation, thereby leading to water-limited environments. With the rising temperature, an increase in stomatal conductance decreased the leaf water potential and growth of Pinus densiflora. That is, the benefits of elevated temperature for photosynthesis were offset by water stresses. For NPP dynamics under temperature change only, we modeled decreases in NPP of $-9.89 \%,-11.69 \%,-9.75 \%$, and $-13.87 \%$ under RCP $2.6,4.5,6.0$, and 8.5 , respectively, compared to baseline. Mean annual temperatures were projected to increase by 1.2, 1.56, 1.29 , and $2.14^{\circ} \mathrm{C}$ under RCP $2.6,4.5,6.0$, and 8.5, respectively, compared to baseline. That is, there was an approximately $7 \%$ reduction of NPP per degree celsius increase in temperature. These results were obtained through the positive influence of temperature on plant and microbial respiration, leading to reduced NPP.

For the scenario of $\mathrm{CO}_{2}$ change alone, the improvements of GPP and NPP were modeled compared to baseline (Figure 3, third column). There was a positive relationship between $\mathrm{CO}_{2}$ concentration and photosynthesis rate due to $\mathrm{CO}_{2}$ fertilizer effects, as expected. However, we noted that elevated $\mathrm{CO}_{2}$ also stimulated soil respiration from increased litter inputs into the soil (explained in further detail in Section 3.3). The ratios of NPP to GPP were $0.5059,0.5142,0.5157$, and 0.5205 under RCP 2.6, 4.5, 6.0, and 8.5 , respectively.

When all of the climate variables were considered together, which included changes in precipitation, temperature, and atmospheric $\mathrm{CO}_{2}$ concentration, increases in GPP of $5.51 \%$, $10.85 \%, 12.16 \%$, and $19.74 \%$ under RCP2.6, 4.5, 6.0, and 8.5, respectively, were modeled compared to baseline (Figure 3, fourth column). We noted that the sums of changes in GPP under the individual climate change scenarios were 4, 7, and $12 \%$ smaller than those under all-considered RCP 2.6, 4.5, and 8.5, respectively. The corresponding case for RCP6.0 was not considerably different (due to relatively small changes in precipitation). That is, the beneficial influences of elevated $\mathrm{CO}_{2}$ on the GPP of Pinus densiflora were not fully restored due to nutrient limitations. Increases in precipitation during growing seasons under climate change scenarios (see Table 1) caused increased nutrient leaching and thus reduced nutrient uptake. Higher NPP was modeled as climate change scenarios become more pronounced in responses to GPP dynamics under climate change. 

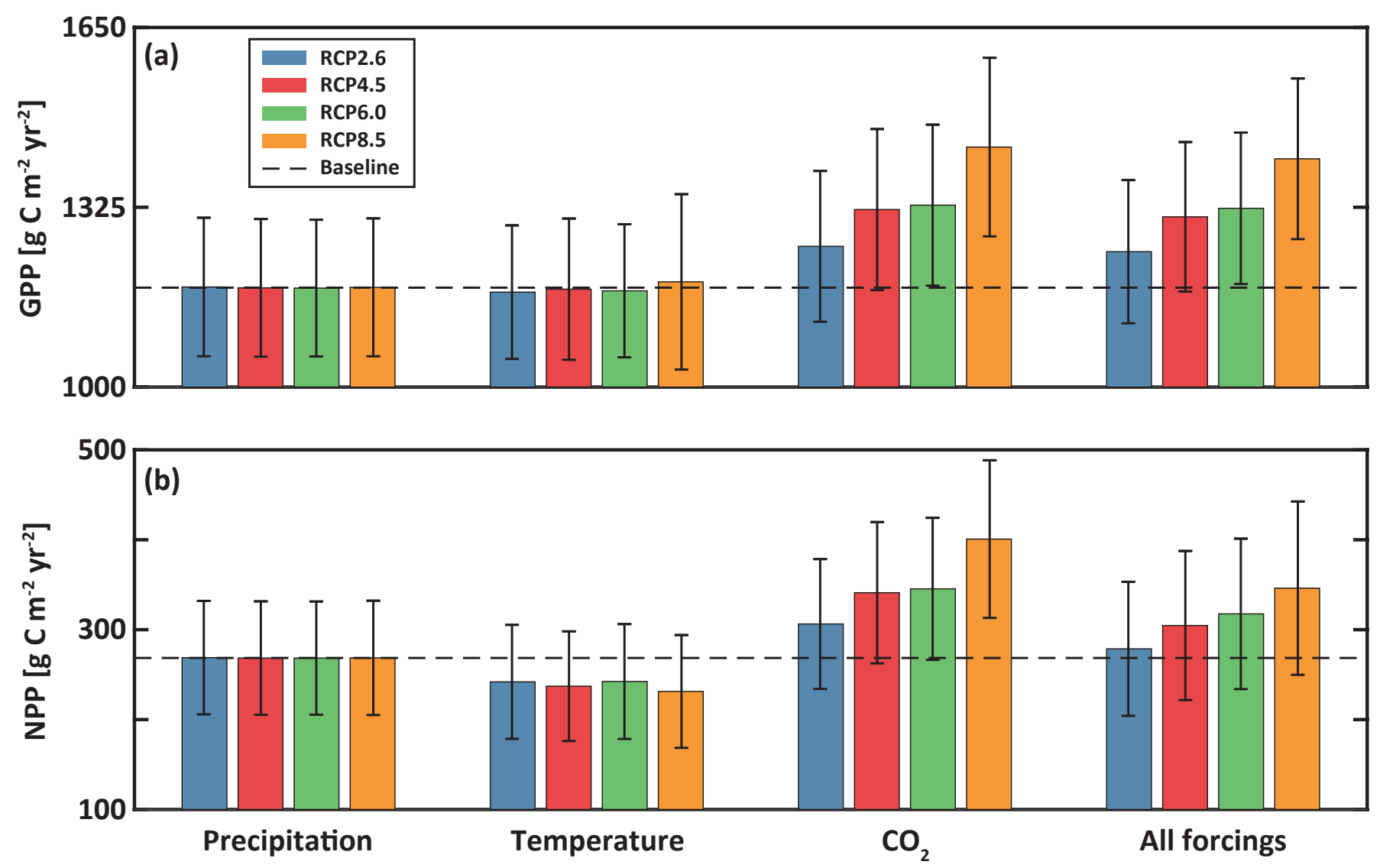

Figure 3. Projected (a) GPP and (b) NPP over the 50-year study period for the scenario of precipitation change alone (first column), temperature change alone (second column), $\mathrm{CO}_{2}$ change alone (third column), and all together (fourth column) under RCP 2.6 (blue), 4.5 (red), 6.0 (green), and 8.5 (orange) for the 2050s (from 2036 to 2065). Error bars are standard deviations. The variables at baseline, climate conditions based on the 2010s (from 1986 to 2015), are shown in dashed lines.

\subsection{Soil $\mathrm{CO}_{2}$ and $\mathrm{N}_{2} \mathrm{O}$ Flux}

Changes in precipitation only had small effects on soil $\mathrm{CO}_{2}$ and $\mathrm{N}_{2} \mathrm{O}$ fluxes. These changes were less than $1 \%$ compared to baseline (Figure 4). These inconsiderable alterations were mainly due to similar litterfall amounts between baseline and climate change scenarios in response to changes in precipitation. For the case of temperature change only, we modeled approximately 0.97 and $23.18 \%$ increases of soil $\mathrm{CO}_{2}$ and $\mathrm{N}_{2} \mathrm{O}$ fluxes, respectively, per $1{ }^{\circ} \mathrm{C}$ increase in mean air temperature. The increased temperature promoted the growth of soil microbes and thus stimulated soil $\mathrm{CO}_{2}$ and $\mathrm{N}_{2} \mathrm{O}$ fluxes. We noted, under elevated $\mathrm{CO}_{2}$ change only, an increase in soil $\mathrm{CO}_{2}$ fluxes, but a decrease in soil $\mathrm{N}_{2} \mathrm{O}$ fluxes. Stimulated leaf photosynthetic $\mathrm{CO}_{2}$ fixation, due to a high internal $\mathrm{CO}_{2}$ level, naturally increased litterfall and thus soil respiration. The reduced soil $\mathrm{N}_{2} \mathrm{O}$ emissions were mainly explained by an increase in nutrient uptake of Pinus densiflora to meet its growth demands, resulting in reduced soil nitrogen and losses as $\mathrm{N}_{2} \mathrm{O}$ via denitrification. When all of the climate variables were considered together, changes in soil $\mathrm{CO}_{2}$ fluxes of 4.30 , $7.62,8.05$, and $12.90 \%$ while changes in soil $\mathrm{N}_{2} \mathrm{O}$ fluxes of $11.53,5.39,-3.49$, and $-2.89 \%$ were modeled under RCP 2.6, 4.5, 6.0, and 8.5, respectively, compared to baseline. In other words, higher soil $\mathrm{CO}_{2}$ and lower $\mathrm{N}_{2} \mathrm{O}$ emissions were expected under higher greenhouse gas emission scenarios. 

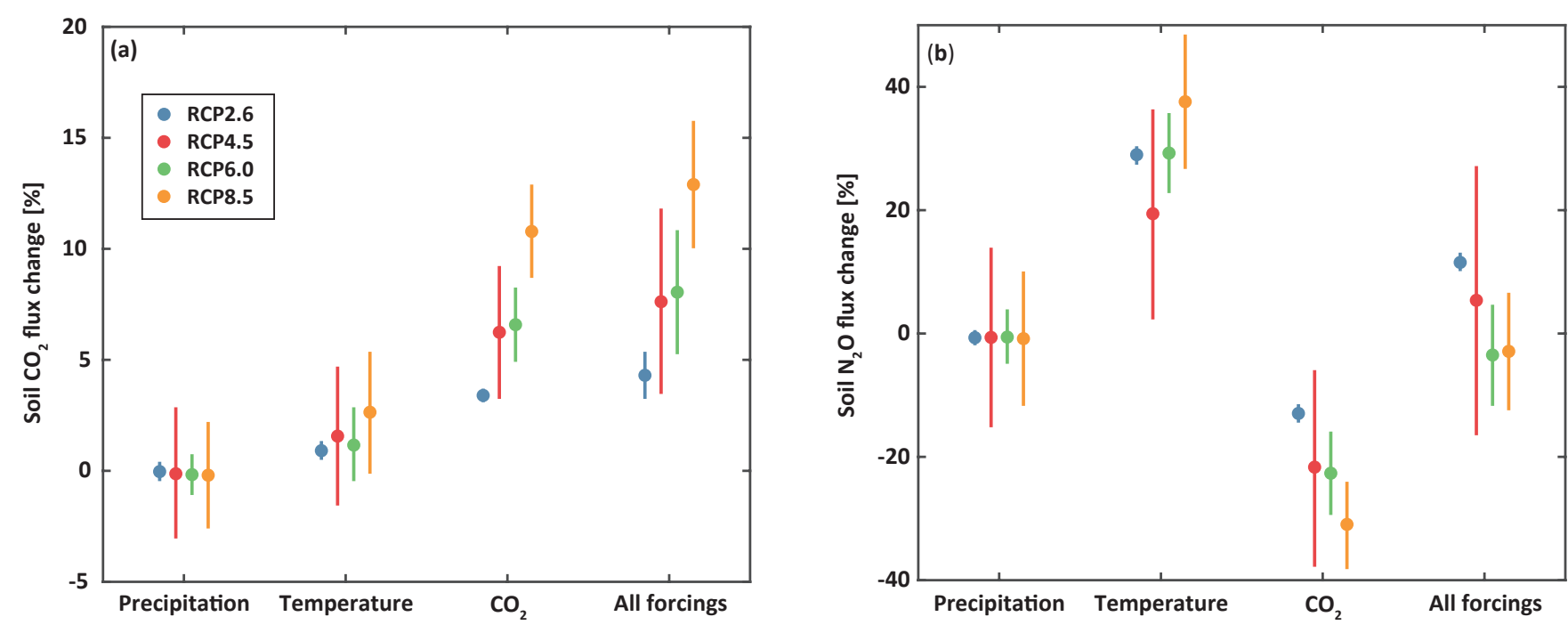

Figure 4. Percent changes in projected soil for (a) $\mathrm{CO}_{2}$ and (b) $\mathrm{N}_{2} \mathrm{O}$ over the 50-year study period for the scenario of precipitation change alone (first column), temperature change alone (second column), $\mathrm{CO}_{2}$ change alone (third column), and all together (fourth column) under RCP 2.6 (blue), 4.5 (red), 6.0 (green), and 8.5 (orange) for the 2050s (from 2036 to 2065) compared with baseline. Error bars and circles are standard deviations and average values, respectively.

\subsection{Inorganic Nitrogen Leaching}

We analyzed the influences of climate change on inorganic nitrogen leaching at the study site to evaluate its environmental risks for receiving water bodies (Figure 5). The increases in precipitation only slightly increased inorganic nitrogen leaching, which was caused by enhanced water percolation (Figure 5a). For the case of temperature change only, considerable increases in inorganic nitrogen leaching of $56.48,71.59,56.45$, and $101.84 \%$, respectively, were modeled compared to baseline (Figure $5 b$ ). Warming stimulated microbial activity and led to higher nitrification and mineralization rates. Additionally, the high solubility and negative charge of nitrate accelerated its losses. As atmospheric $\mathrm{CO}_{2}$ increased alone, inorganic nitrogen leaching decreased (Figure 5c). The relatively high rates of photosynthesis of Pinus densiflora due to $\mathrm{CO}_{2}$ fertilization effects increased nitrogen uptake and thus reduced nitrogen available for leaching. We noted that, when all the climate variables were considered together, nitrogen leaching reduced as climate scenarios became severe (Figure 5d).

\subsection{Evapotranspiration}

We estimated the impacts of changes in precipitation, temperature, and $\mathrm{CO}_{2}$ concentration separately and in combination on evaporation and transpiration of Pinus densiflora (Figure 6a) under RCP 2.6, RCP 4.5, RCP 6.0, and RCP 8.5. For the case of increases in precipitation alone, almost no changes in evaporation were modeled (less than $0.3 \%$ compared to baseline). These results indicated that, at the study site, the processes of surface evaporation were limited by energy availability rather than water. These limitations were also explained by the numerical experiments of temperature change-only scenarios. We modeled an approximately $5.71 \mathrm{~mm} \mathrm{yr}^{-1}$ increase of evaporation per degree Celsius increase in temperature. For the case of $\mathrm{CO}_{2}$ concentration alone, slight decreases in evaporation were modeled. The stimulated photosynthesis due to $\mathrm{CO}_{2}$ fertilizer effects enhanced biomass allocation to leaves, developing increased shading covers that reduced the energy available for evaporation. When all of the climate variables were considered together, increases in evaporation of $4.51,5.84,4.61$, and $8.14 \%$ were modeled under RCP 2.6, RCP 4.5, RCP 6.0, and RCP 8.5 , respectively. That is, temperature was the most important regulator between the other climate variables in positively affecting evaporation. 
(a)

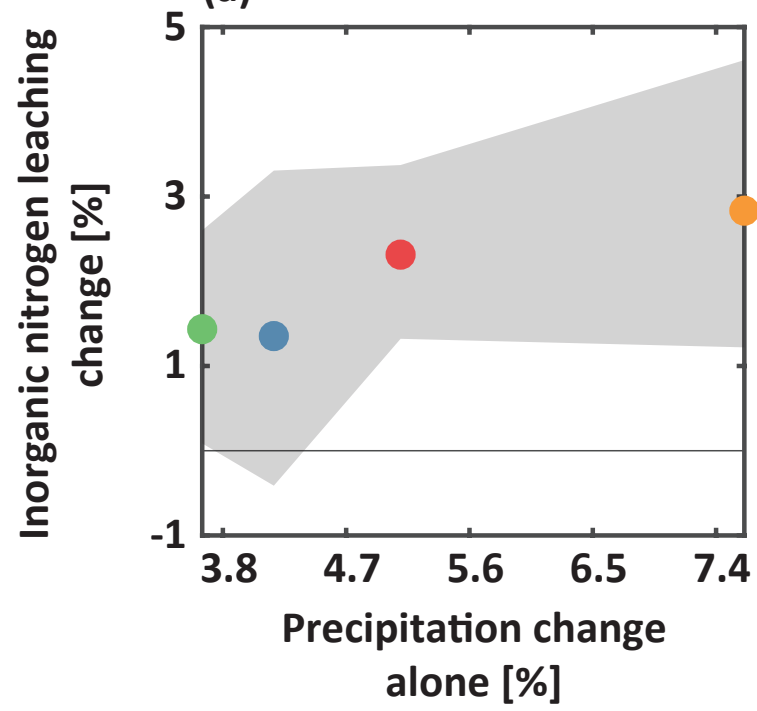

(c)

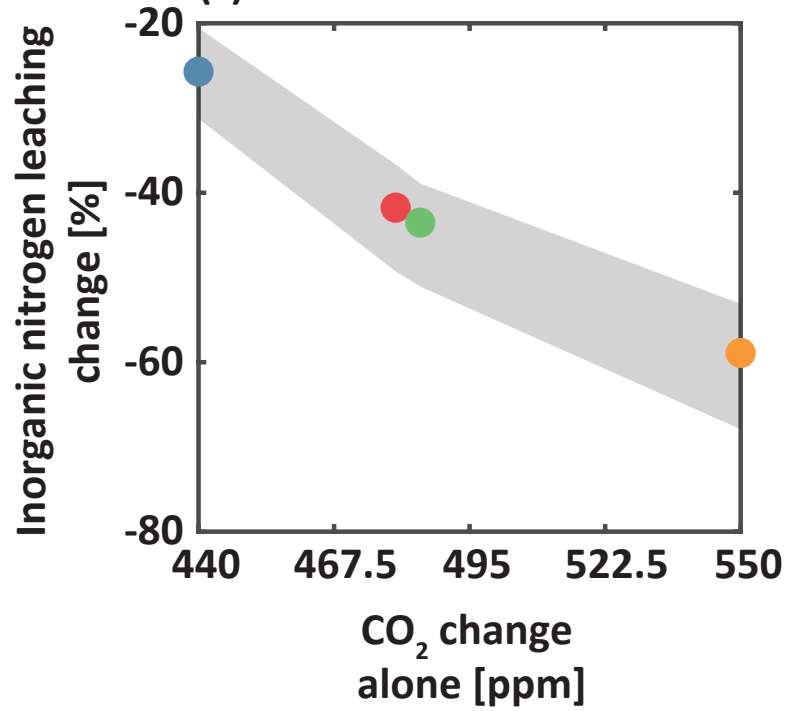

(b)

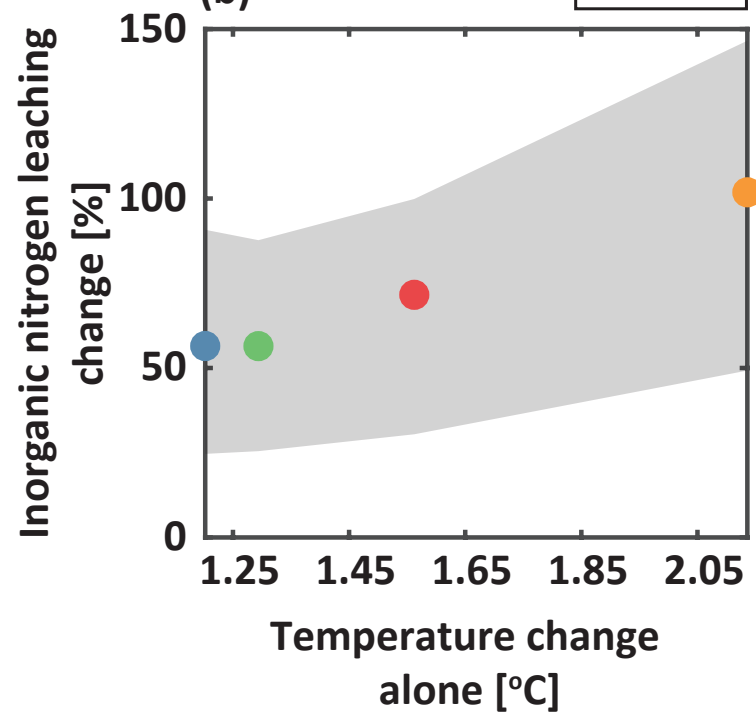

(d)

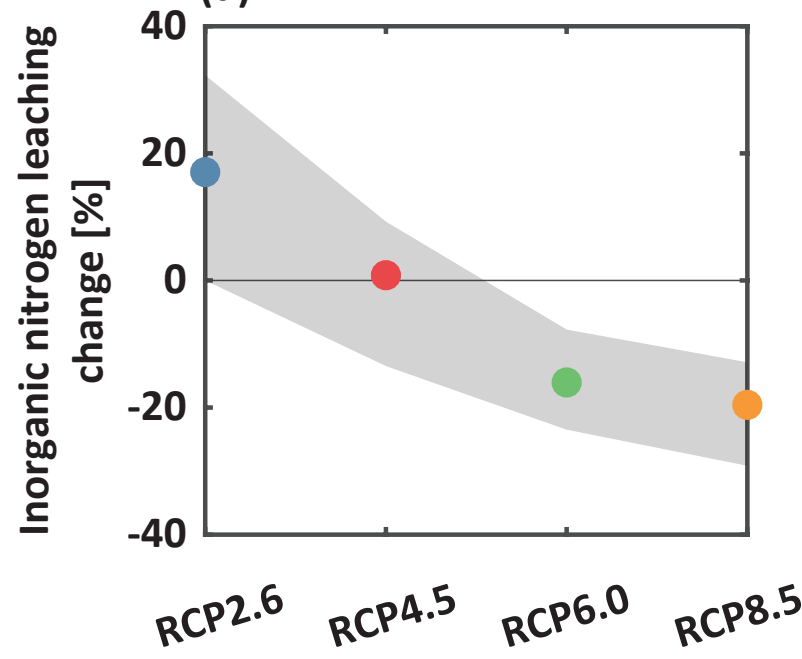

Figure 5. Percent changes in projected inorganic leaching at a depth of $3 \mathrm{~m}$ compared with baseline for the scenario of (a) precipitation change alone, (b) temperature change alone, (c) $\mathrm{CO}_{2}$ change alone, and (d) all together under RCP 2.6 (blue), 4.5 (red), 6.0 (green), and 8.5 (orange) for the 2050s (from 2036 to 2065). Shaded areas represent the 25th to 75 th percentile intervals.

We explored the transpiration of Pinus densiflora under climate change (Figure 6b). For the case of precipitation change only, we modeled slightly higher water losses through transpiration of $0.52,0.65,0.46,0.85 \%$ under RCP 2.6, RCP 4.5, RCP 6.0, and RCP 8.5, respectively, due to increased water availability. For the cases of temperature change only, the rising temperature increased the atmospheric vapor pressure deficit and thus the gradient of water between the atmosphere and leaf interior. These processes resulted in increased transpiration under elevated temperature scenarios. We estimated an approximately $2.53 \mathrm{~mm} \mathrm{yr}^{-1}$ increase in transpiration per degree Celsius increase in temperature. For the case of elevated $\mathrm{CO}_{2}$ alone, we noted that, although $\mathrm{CO}_{2}$ fertilizer effects reduced 
the stomatal opening of Pinus densiflora, slight increases in transpiration of 1.08, 1.29, 1.19, and $1.39 \%$ under RCP 2.6, RCP 4.5, RCP 6.0, and RCP 8.5, respectively, were modeled due to enhanced photosynthesis rates. We found that the combined impacts of precipitation changes and rising temperature and $\mathrm{CO}_{2}$ levels on the transpiration of Pinus densiflora were not far from the additive.
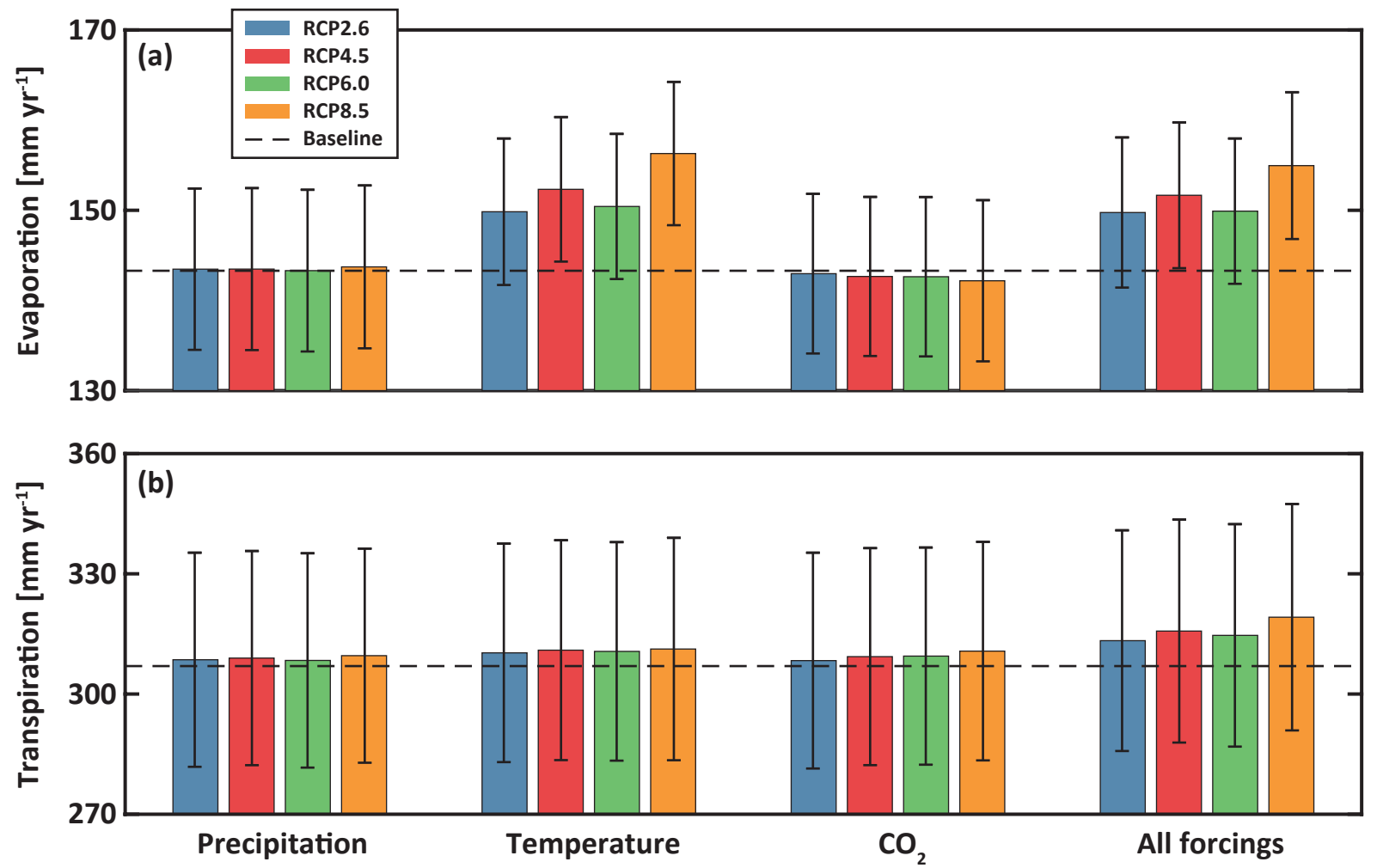

Figure 6. Projected (a) evaporation and (b) transpiration over the 50-year study period for the scenario of precipitation change alone (first column), temperature change alone (second column), $\mathrm{CO}_{2}$ change alone (third column), and all together (fourth column) under RCP 2.6 (blue), 4.5 (red), 6.0 (green), and 8.5 (orange) for the 2050s (from 2036 to 2065). Error bars are standard deviations. The variables at baseline, climate conditions based on the 2010s (from 1986 to 2015), are shown in dashed lines.

\subsection{Water Use Efficiency}

Due to increases in both evapotranspiration and GPP under climate change scenarios, we evaluated water use efficiency (defined as GPP per unit water uptake) to explore the environmental sustainability of Pinus densiflora (Figure 7). For the case of precipitation change only (Figure 7a), water use efficiency was not considerably influenced by increases in precipitation. This finding indicated that water stress was not one of the limiting factors to prevent the growth of Pinus densiflora at the study site. When Pinus densiflora were exposed to an increasing water deficit caused by heat-induced drought stress, decreases in water use efficiency of 2.84, 3.07, 2.83, and 2.88\% were modeled under RCP 2.6, RCP 4.5, $\mathrm{RCP} 6.0$, and $\mathrm{RCP} 8.5$, respectively (Figure 7b). For the case of $\mathrm{CO}_{2}$ change alone, water use efficiency almost linearly increased with rising atmospheric $\mathrm{CO}_{2}$ concentration (Figure 7c). We found an increase in water use efficiency of $6.08 \mathrm{gC} \mathrm{g}^{-1} \mathrm{H}_{2} \mathrm{O}$ per ppm increase of $\mathrm{CO}_{2}$. When all of the climate change variables were considered together, the benefits of $\mathrm{CO}_{2}$-induced improvements in water use efficiency were lowered to 2.57, 6.77, 8.70, $13.68 \%$ under RCP $2.6, \mathrm{RCP} 4.5$, RCP 6.0 , and RCP 8.5 , respectively, compared to baseline (Figure 7d). 

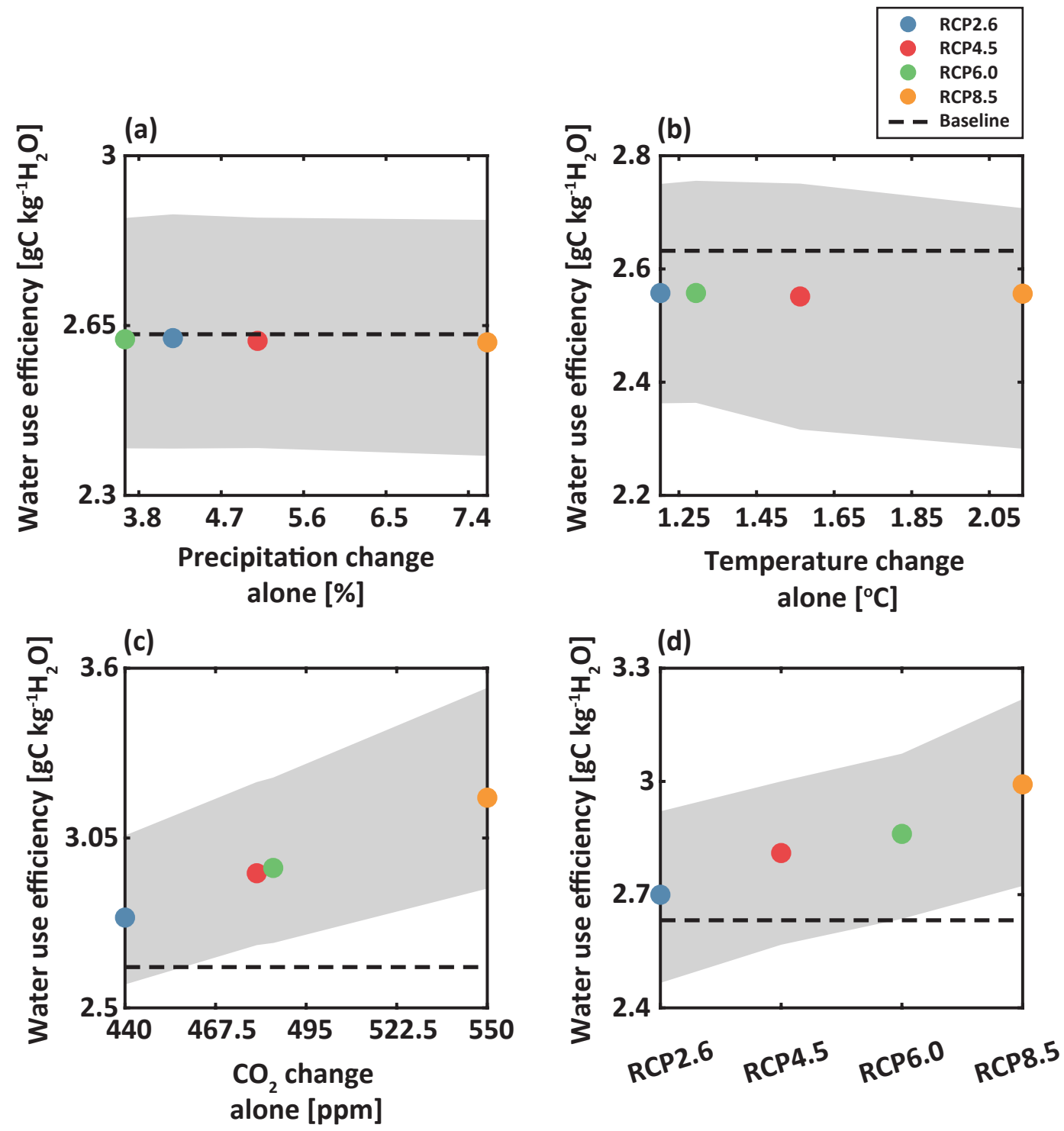

Figure 7. Projected water use efficiency for the scenario of (a) precipitation change alone, (b) temperature change alone, $(\mathbf{c}) \mathrm{CO}_{2}$ change alone, and (d) all together under RCP 2.6 (blue), 4.5 (red), 6.0 (green), and 8.5 (orange) for the 2050s (from 2036 to 2065) compared with baseline. Shaded areas represent the 25th to 75 th percentile intervals. The variables at baseline are shown in dashed lines.

\section{Discussion}

Climate change is already ongoing and more change is expected. Climate change mitigation is thus, and will continue to be, a major concern for human beings in the next decades [30,43]. Several studies have demonstrated the essential role of maintaining and planting trees as a way of tackling climate change $[9,18,44]$. However, there were still debates on whether the benefits of $\mathrm{CO}_{2}$ fertilizer effects on GPP and NPP were offset by the negative influences of increased temperatures and changes in precipitation, such as heat stress and drought [45-47]. Elevated temperature reduced soil moisture and triggered stomatal closure due to increases in transpiration, leading to negative impacts on the growth of Pinus densiflora, which could be compensated by elevated $\mathrm{CO}_{2}$, as shown in free air $\mathrm{CO}_{2}$ enrichment (FACE) studies [16,48-50]. In this study, to explore interactions between climate change and forests, we studied separately and in combination the impacts of climate change on the growth of Pinus densiflora for the case of a research forest in South Korea. Our results demonstrated that the stimulated photosynthetic $\mathrm{CO}_{2}$ fixation and water use efficiency of Pinus densiflora due to elevated $\mathrm{CO}_{2}$ outweighed temperature 
and precipitation-driven decreases in GPP and NPP. We also found that, at the study site, increases in the GPP and NPP of Pinus densiflora were modeled as climate change scenarios became severe. These results indicated that Pinus densiflora could serve as a carbon buffer against climate change.

Soil $\mathrm{N}_{2} \mathrm{O}$ flux and nitrogen leaching have been important concerns associated with climate change $[30,51]$. This is mainly because $\mathrm{N}_{2} \mathrm{O}$ has, on an equivalent mass basis, a greenhouse gas 300 times more potent than $\mathrm{CO}_{2}$, although the concentration of atmospheric $\mathrm{N}_{2} \mathrm{O}$ is much lower than that of $\mathrm{CO}_{2}$. Nitrogen leaching also causes serious environmental damage, such as infant methemoglobinemia and eutrophication $[30,52,53]$. Several studies have noted that increases in precipitation and temperature would lead to increases in soil $\mathrm{N}_{2} \mathrm{O}$ emissions and nitrogen leaching due to enhanced subsurface water flux and organic matter decomposition, respectively [54,55]. In line with previous studies, our results also showed that soil $\mathrm{N}_{2} \mathrm{O}$ emission and nitrogen leaching would reduce as the intensity of climate change scenarios increased. Elevated atmospheric $\mathrm{CO}_{2}$ stimulated the growth of Pinus densiflora and thus increased nitrogen uptake, leading to a decrease in soil inorganic nitrogen.

Previous studies noted that changes in precipitation and temperature due to climate change resulted in increases in evapotranspiration [56-58]. Improved soil water availability and molecule kinetic energy due to warming led to an increase in evapotranspiration rates. In line with the findings, our results also showed that elevated atmospheric $\mathrm{CO}_{2}$ decreased evaporation, but increased transpiration. The elevated $\mathrm{CO}_{2}$ stimulated the growth of Pinus densiflora, leading to increases in water uptake and thus decreases in soil moisture available for evaporation. Although water loss through evapotranspiration increased under climate change, we found improvements in the water use efficiency of Pinus densiflora induced by elevated $\mathrm{CO}_{2}$-induced stomatal closure.

There are still debates on whether planting and maintaining trees will act as a pivotal role in mitigating climate change $[18,23,24]$. Although forest management could reduce atmospheric $\mathrm{CO}_{2}$ through photosynthesis and sequestrate carbon in the soil, the effects of changes in albedo and cloud cover induced by tree planting would offset the benefits of reducing the atmospheric concentration of $\mathrm{CO}_{2}$ [43]. It has been reported that the benefits of forest management to mitigate climate change are site-specific, depending on local ecological and climate conditions $[10,11,44]$. These intertwined processes were not considered in this study and might be thus dealt with together to further confirm whether trees have a carbon-absorbing capacity under climate change. The results obtained in this study are dependent on the parameters and structures of the model. Further numerical and experimental research is thus required to evaluate the uncertainties of the modeled results.

\section{Conclusions}

In this study, we examined the growth of Pinus densiflora under climate change for the case of the Gwangneung Experimental Forest, South Korea using a coupled ecohydrological and biogeochemical model, ecosys. We found that the most dominant tree species in South Korea, Pinus densiflora, could act as a nature-based solution to mitigate climate change by increases in GPP, NPP, and water use efficiency and decreases in soil $\mathrm{N}_{2} \mathrm{O}$ emission and nitrogen leaching. That is, maintaining Pinus densiflora may have great potential to aid climate change mitigation by absorbing greenhouse gas and could be considered to be an environmentally friendly practice to mitigate climate change. To extend our results, we recommend that short- and long-term regional simulations and analyses be conducted to further assess the growth of Pinus densiflora under climate change.

Author Contributions: Conceptualization and formal analysis, D.K.W.; writing-original draft preparation, D.K.W., W.D.; writing-review and editing, D.K.W. All authors have read and agreed to the published version of the manuscript.

Funding: This research was supported by the Bisa Research Grant of Keimyung University in 2020.

Institutional Review Board Statement: Not applicable. 
Informed Consent Statement: Not applicable.

Data Availability Statement: Not applicable.

Acknowledgments: This research was supported by the Bisa Research Grant of Keimyung University in 2020 .

Conflicts of Interest: The authors declare no conflict of interest.

\section{References}

1. Kemp, D.B.; Eichenseer, K.; Kiessling, W. Maximum rates of climate change are systematically underestimated in the geological record. Nat. Commun. 2015, 6, 8890. [CrossRef]

2. Williams, I.N.; Torn, M.S.; Riley, W.J.; Wehner, M.F. Impacts of climate extremes on gross primary production under global warming. Environ. Res. Lett. 2014, 9, 094011. [CrossRef]

3. Gaertner, B.A.; Zegre, N.; Warner, T.; Fernandez, R.; He, Y.; Merriam, E.R. Climate, forest growing season, and evapotranspiration changes in the central Appalachian Mountains, USA. Sci. Total Environ. 2019, 650, 1371-1381. [CrossRef]

4. Haag, I.; Jones, P.D.; Samimi, C. Central Asia's Changing Climate: How Temperature and Precipitation Have Changed across Time, Space, and Altitude. Climate 2019, 7, 123. [CrossRef]

5. Min, S.K.; Son, S.W.; Seo, K.H.; Kug, J.S.; An, S.I.; Choi, Y.S.; Jeong, J.H.; Kim, B.M.; Kim, J.W.; Kim, Y.H.; et al. Changes in weather and climate extremes over Korea and possible causes: A review. Asia-Pac. J. Atmos. Sci. 2015, 51, 103-121. [CrossRef]

6. Im, E.S.; Thanh, N.X.; Kim, Y.H.; Ahn, J.B. 2018 summer extreme temperatures in South Korea and their intensification under $3^{\circ} \mathrm{C}$ global warming. Environ. Res. Lett. 2019, 14, 094020. [CrossRef]

7. Korea Meteorological Administration. Annual Report for 2018 Extreme Climate; Korea Meteorological Administration: Seoul, Korea, 2019; pp. 1-198.

8. Bax, V.; Castro-Nunez, A.; Francesconi, W. Assessment of Potential Climate Change Impacts on Montane Forests in the Peruvian Andes: Implications for Conservation Prioritization. Forests 2021, 12, 375. [CrossRef]

9. Camarero, J.J.; Valeriano, C.; Gazol, A.; Colangelo, M.; Sanchez-Salguero, R. Climate Differently Impacts the Growth of Coexisting Trees and Shrubs under Semi-Arid Mediterranean Conditions. Forests 2021, 12, 381. [CrossRef]

10. Fibbi, L.; Moriondo, M.; Chiesi, M.; Bindi, M.; Maselli, F. Impacts of climate change on the gross primary production of Italian forest. Ann. For. Sci. 2019, 79, 59. [CrossRef]

11. Kim, J.S.; Son, C.Y.; Moon, Y.I.; Lee, J.H. Seasonal rainfall variability in Korea within the context of different evolution patterns of the central Pacific El Nino. J. Water Clim. Chang. 2017, 8, 412-422. [CrossRef]

12. Byun, J.G.; Lee, W.K.; Kim, S.H.; Choi, J.K.; Lee, Y.J. The Relationship Between Tree Radial Growth and Topographic and Climatic Factors in Red Pine and Oak in Central Regions of Korea. J. Korean Soc. For. Sci. 2010, 99, 908-913.

13. Choung, Y.; Lee, J.; Cho, S.; Noh, J. Review on the succession process of Pinus densiflora forests in South Korea: Progressive and disturbance-driven succession. J. Ecol. Environ. 2020, 44, 16. [CrossRef]

14. Lim, J.H.; Shin, J.H.; Jin, G.Z.; Chun, J.H.; Oh, J.S. Forest Stand Structure, Site Characteristics and Carbon Budget of the Kwangneung Natural Forest in Korea. Korean J. Agric. For. Meteorol. 2003, 5, 101-109.

15. Chun, J.H.; Lee, C.B. Assessing the Effects of Climate Change on the Geographic Distribution of Pinus densiflora in Korea using Ecological Niche Model. Korean J. Agric. For. Meteorol. 2013, 15, 219-233. [CrossRef]

16. Kim, M.; Lee, W.K.; Nam, K.; Yu, H.; Choi, S.E.; Kim, C.G. Estimating Stand Volume Pinus densiflora Forest Based on Climate Change Scenario in Korea. J. Korean For. Soc. 2014, 103, 105-112. [CrossRef]

17. Byun, J.G.; Lee, W.K.; Kim, M.; Kwak, D.A.; Kwak, H.; Park, T.; Byun, W.H.; Son, Y.; Choi, J.K.; Lee, Y.J.; et al. Radial growth response of Pinus densiflora and Quercus spp. to topographic and climatic factors in South Korea. J. Plant Ecol. 2013, 6, 380-392. [CrossRef]

18. Popkin, G. How much can forests fight climate change? Nature 2019, 565, 280-282. [CrossRef] [PubMed]

19. Tor-ngern, P.; Leksungnoen, N. Investigating carbon dioxide absorption by urban trees in a new park of Bangkok, Thailand. BMC Ecol. 2020, 20, 2020. [CrossRef]

20. Nunes, L.J.; Meireles, C.I.; Gomes, C.J.P.; Ribeiro, N.M.A. Forest Contribution to Climate Change Mitigation:Management Oriented to Carbon Capture and Storage. Climate 2020, 8, 21. [CrossRef]

21. Pan, Y.; Birdsey, R.A.; Fang, J.; Houghton, R.; Kauppi, P.E.; Kurz, W.A.; Phillips, O.L.; Shvidenko, A.; Lewis, S.L.; Canadell, J.G.; et al. A Large and Persistent Carbon Sink in the World's Forests. Science 2011, 333, 988-993. [CrossRef]

22. Bonan, G.B. Forests and Climate Change: Forcings, Feedbacks, and the Climate Benefits of Forests. Science 2008, 320, 1444-1449. [CrossRef]

23. Xiao, J.L.; Zeng, F.; He, Q.L.; Yao, Y.X.; Han, X.; Shi, W.Y. Responses of Forest Carbon Cycle to Drought and Elevated CO 2 . Atmosphere 2021, 12, 212. [CrossRef]

24. Konapala, G.; Mishra, A.K.; Wada, Y.; Mann, M.E. Climate change will affect global water availability through compounding changes in seasonal precipitation and evaporation. Nat. Commun. 2020, 11, 3044. [CrossRef]

25. Yoon, T.K.; Noh, N.J.; Chung, H.; Yang, A.R.; Son, Y. Soil Nitrogen Transformations and Availability in Upland Pineand Bottomland Alder Forests. Forests 2015, 6, 2941-2958. [CrossRef] 
26. Noh, N.J.; Kim, C.; Bae, S.W.; Lee, W.K.; Yoon, T.K.; Muraoka, H.; Son, Y. Carbon and nitrogen dynamics in a Pinus densiflora forest with low and high stand densities. J. Plant Ecol. 2013, 6, 368-379. [CrossRef]

27. Hengl, T.; de Jesus, J.M.; Heuvelink, G.B.M.; Gonzalez, M.R.; Kilibarda, M.; Blagotic, A.; Shangguan, W.; Wright, M.N.; Geng, X.; Bauer-Marschallinger, B.; et al. SoilGrids250m: Global gridded soil information based on machine learning. PLoS ONE 2017, 12, e0169748. [CrossRef]

28. Saxton, K.E.; Rawls, W.J. Soil Water Characteristic Estimates by Texture and Organic Matter for Hydrologic Solutions. Soil Sci. Soc. Am. J. 2006, 70, 1569-1578. [CrossRef]

29. Yun, S.J.; Chun, J. Long-term ecological research on Korean forest ecosystems: The current status and challenges. Ecol. Res. 2018, 33, 1289-1302. [CrossRef]

30. Woo, D.K.; Riley, W.J.; Wu, Y. More Fertilizer and Impoverished Roots Required for Improving Wheat Yields and Profits under Climate Change. Field Crop. Res. Revis. 2020, 249, 107756. [CrossRef]

31. Woo, D.K.; Riley, W.J.; Paez-Garcia, A.; Marklein, A.R.; Mekonnen, Z.A.; Liu, X.; Ma, X.F.; Blancaflor, E.; Wu, Y. Impoverishing roots will improve wheat yield and profitability through increased water and nitrogen use efficiencies. JGR Biogeosciences. 2021, 126, e2020JG005829. [CrossRef]

32. Grant, R.F.; Mekonnen, Z.A.; Riley, W.J.; Wainwright, H.M.; Graham, D.; Torn, M.S. Mathematical Modelling of Arctic Polygonal Tundra with Ecosys: 1. Microtopography Determines How Active Layer Depths Respond to Changes in Temperature and Precipitation. JGR Biogeosci. 2017, 122, 3161-3171. [CrossRef]

33. Mekonnen, Z.A.; Riley, W.J.; Grant, R.F. Accelerated nutrient cycling and increased light competition will lead to $21^{\text {st }}$ century shrub expansion in North American Arctic tundra. J. Geophys. Res. Biogeosci. 2018, 123, 1683-1701. [CrossRef]

34. Grant, R.F. A Review of the Canadian Ecosystem Model Ecosys; CRC: Press, Boca Raton, FL, USA, 2001.

35. Grant, R.F.; Jarvis, P.G.; Massheder, J.M.; Hale, S.E.; Moncrieff, J.B.; Rayment, M.; Scott, S.L.; Berry, J.A. Controls on carbon and energy exchange by a black spruce-moss ecosystem: Testing the mathematical model Ecosys with data from the BOREAS Experiment. Glob. Biogeochem. Cycles 2001, 15, 129-147. [CrossRef]

36. Grant, R.F. Nitrogen mineralization drives the response of forest productivity to soil warming: Modelling in Ecosys Vs. Meas. Harvard Soil Heat. Exp. Ecol. Model. 2014, 288, 38-46. [CrossRef]

37. Schaefer, K.; Schwalm, C.R.; Williams, C.; Arain, M.A.; Barr, A.; Chen, J.M.; Davis, K.J.; Dimitrov, D.; Hilton, T.W.; Hollinger, D.Y.; et al. A model-data comparison of gross primary productivity: Results from the North American Carbon Program site synthesis. J. Geophys. Res. 2012, 117, G03010. [CrossRef]

38. Grant, R.F.; Black, T.A.; Jassal, R.S.; Bruemmer, C. Changes in net ecosystem productivity and greenhouse gas exchange with fertlization of Douglas fir: Mathematical modeling in ecosys. J. Geophys. Res. 2010, 115, G04009. [CrossRef]

39. Fatichi, S.; Ivanov, V.Y.; Caporali, E. Simulation of future climate scenarios with a weather generator. Adv. Water Resour. 2010, 34, 448-467. [CrossRef]

40. Grant, R.F. Modeling topographic effects on net ecosystem productivity of boreal black spruce forests. Tree Physiol. 2004, 24, 1-18. [CrossRef] [PubMed]

41. Grant, R.F.; Barr, A.G.; Black, T.A.; Gaumont-Guay, D.; Iwashita, H.; Kidson, J.; McCaughey, H.; Morgenstern, K.; Murayama, S.; Nesic, Z.; et al. Net ecosystem productivity of boreal jack pine stands regenerating from clearcutting under current and future climates. Glob. Chnage Biol. 2007, 13, 1423-1440. [CrossRef]

42. Welegedara, N.P.Y.; Grant, R.F.; Quideau, S.A.; Gupta, S.D. Modelling nitrogen mineralization and plant nitrogenuptake as affected by reclamation cover depth in reclaimedupland forestlands of Northern Alberta. Biogeochemistry 2020, 149, 293-315. [CrossRef]

43. Luyssaert, S.; Marie, G.; Valade, A.; Chen, Y.Y.; Djomo, S.N.; Ryder, J.; Otto, J.; Naudts, K.; Lanso, A.S.; Ghattas, J.; et al. Trade-offs in using European forests to meet climate objectives. Nature 2018, 562, 259-262. [CrossRef]

44. Frenne, P.D.; Lenoir, J.; Luoto, M.; Scheffers, B.R.; Zellweger, F.; Aalto, J.; Ashcroft, M.B.; Christiansen, D.M.; Decocq, G.; Pauw, K.D.; et al. Forest microclimates and climate change: Importance, drivers and future research agenda. Glob. Chang. Biol. 2021, 27, 2279-2297. [CrossRef]

45. Fang, O.; Wang, Y.; Shao, X. The effect of climate on the net primary productivity (NPP) of Pinus koraiensis in the Changbai Mountains over the past 50 years. Trees 2016, 30, 281-294. [CrossRef]

46. Sun, B.; Zhao, H.; Wang, X. Effects of drought on net primary productivity: Roles of temperature, drought intensity, and duration. Chin. Geogr. Sci. 2016, 26, 270-282. [CrossRef]

47. Ngoma, J.; Braakhekke, M.C.; Kruijt, B.; Moors, E.; Supit, I.; Speer, J.H.; Vinya, R.; Leemans, R. Modelling the response of net primary productivity of the Zambezi teak forests to climate change along a rainfall gradient in Zambia. Biogeosciences 2019, 16, 3853-3867. [CrossRef]

48. Ainsworth, E.A.; Long, S.P. What have we learned from 15 years of free-air $\mathrm{CO}_{2}$ enrichment (FACE)? A meta-analytic review of the responses of photosynthesis, canopy properties and plant production to rising $\mathrm{CO}_{2}$. New Phytol. 2005, 165, 351-371. [CrossRef] [PubMed]

49. Norby, R.J.; Zak, D.R. Ecological Lessons from Free-Air $\mathrm{CO}_{2}$ Enrichment (FACE) Experiments. Annu. Rev. Ecol. Evol. Syst. 2011, 42, 181-203. [CrossRef] 
50. Sperry, J.S.; Venturas, M.D.; Todd, H.N.; Trugman, A.T.; Anderegg, W.R.L.; Wang, Y.; Tai, X. The impact of rising $\mathrm{CO}_{2}$ and acclimation on the response of US forests to global warming. Proc. Natl. Acad. Sci. USA 2019, 116, 25734-25744. [CrossRef] [PubMed]

51. Del Grosso, S.J.; Parton, W.J. Climate change increases soil nitrous oxide emissions. New Phytol. 2012, 196, 327-328. [CrossRef]

52. Gundersen, P.; Schmidt, I.K.; Raulund-Rasmussen, K. Leaching of nitrate from temperate forests-effects of air pollution and forest management. Can. Sci. 2006, 14, 1-57. [CrossRef]

53. Woo, D.K.; Kumar, P. Role of Micro-topographic Variability on Mean Age of Soil Nitrogen in Intensively Managed Landscape. Water Resour. Res 2017, 53, 8404-8422. [CrossRef]

54. Phillips, R.L.; McMillan, A.M.S.; Palmada, T.; Dando, J.; Giltrap, D. Temperature effects on $\mathrm{N}_{2} \mathrm{O}$ and $\mathrm{N}_{2}$ denitrificationendproducts for a New Zealand pasture soil. N. Z. J. Agric. Res. 2015, 58, 89-95. [CrossRef]

55. Geng, S.; Chen, Z.; Han, S.; Wang, F.; Zhanga, J. Rainfall reduction amplifies the stimulatory effect of nitrogen addition on $\mathrm{N}_{2} \mathrm{O}$ emissions from a temperate forest soil. Sci. Rep. 2017, 7, 43329. [CrossRef] [PubMed]

56. Snyder, R.L.; Moratiel, R.; Zhenwei Song, A.S.; Jomaa, I. Evapotranspiration response to climate change. Acta Hortic. 2011, 922, 91-98. [CrossRef]

57. Lindner, M.; Fitzgerald, J.B.; Zimmermann, N.E.; Reyerc, C.; Delzon, S.; der Maaten, E.; Schelhaas, M.J.; Lasch, P.; Eggers, J.; der Maaten-Theunissen, M.; et al. Climate change and European forests: What do we know, what are the uncertainties, and what are the implications for forest management? J. Environ. Manag. 2014, 2014, 69-83. [CrossRef] [PubMed]

58. Hadiwijaya, B.; Pepin, S.; Isabelle, P.E.; Nadeau, D.F. The Dynamics of Transpiration to EvapotranspirationRatio under Wet and Dry Canopy Conditions in aHumid Boreal Forest. Forests 2020, 11, 237. [CrossRef] 